\section{DIGITAL COMMONS \\ @ UNIVERSITY OF SOUTH FLORIDA}

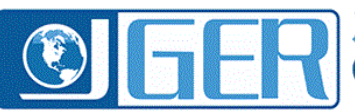

Journal of

Global Education and Research

\title{
Slow down and smell the eucalypts: Blue Gum Community School and the slow education movement
}

Stephen J. Smith

University of Newcastle, stephen.j.smith@newcastle.edu.au

Follow this and additional works at: https://digitalcommons.usf.edu/jger

\section{Part of the Education Commons}

This Refereed Article is brought to you for free and open access by the M3 Center at the University of South Florida Sarasota-Manatee at Digital Commons @ University of South Florida. It has been accepted for inclusion in Journal of Global Education and Research by an authorized editor of Digital Commons @ University of South Florida. For more information, please contact digitalcommons@usf.edu.

\section{Recommended Citation}

Smith, S. J. (2017). Slow down and smell the eucalypts: Blue Gum Community School and the slow education movement. Journal of Global Education and Research, 1(1), 16-34. https://www.doi.org/ 10.5038/2577-509X.1.1.1006

Revisions

Submission date: 04.03.2017

1st Revision: 10.03 .2017

Acceptance: 10.21.2017 
Smith: Slow down and smell the eucalypts: Blue Gum Community School and the slow education movement

\title{
Slow Down and Smell the Eucalypts: Blue Gum Community School and the Slow Education Movement
}

\author{
Stephen J. Smith \\ School of Humanities \& Social Science, \\ University of Newcastle, Australia \\ stephen.j.smith@newcastle.edu.au
}

\begin{abstract}
This paper investigates and analyses the features of a non-mainstream pedagogy, educational context and learning environment by presenting a counter-model which contrasts with the currently dominant educational project, an emergent global educational movement known as the Slow Education Movement. It demonstrates how the associated principles and praxes of a particular ethos and its philosophical foundations guide teaching and learning. Set against the background of the Slow Education Movement, the paper draws on a case study to illustrate some of the foundational principles and practices of that movement. The paper outlines the educational ethos, philosophy, processes and practices of Blue Gum Community School and how the teaching and learning practices contribute to the development of skills that increase student resilience, positive emotion, engagement and meaning in a learning environment of authentic student research and academic rigor. The paper fulfils an introductory and exploratory purpose into the area of nonmainstream education which, it is envisaged, will be built upon through further research and deeper analysis of the methods and strategies employed in the teaching and learning processes employed in such educational environments.
\end{abstract}

Keywords: non-mainstream education, strengths-based education, school

\section{Introduction}

"Anything worth doing is worth doing slowly."

(Mae West, actress)

"There is more to life than increasing its speed."

(Mahatma Gandhi)

In a constantly changing world overwhelmingly dominated by technology and ever-increasing complexity, schooling systems continually face challenges as they seek to address such big picture questions as what is the purpose of education, what it means to educate, how children learn (best), what children should learn which will prepare them for their futures and how they should best engage in the learning process. Answers to these questions hinge upon the ways in which communities and nations define Education and who, within those communities and nations, is bestowed with the responsibility to define it (van Oostrum, 2014). Different national, regional and local needs, social and cultural expectations and ideological impetuses drive the approaches and perspectives towards educating children. The ways in which members of a community are 
educated and the processes and practices by which knowledge and skills are imparted are influenced by contemporary ideological, political, social, cultural, economic, philosophical and psychological trends, all of which have an impact upon the content, delivery and desired goals and outcomes of education.

Most recently, the exponential increase in technological and technical advances, the relative ease and access to information globally, and increasing demands and expectations placed on learners, require the development of effective teaching strategies and methods for learning effectiveness in the development and delivery of a system of education which is meaningful and where the knowledge and skills learned are relevant for one's successful navigation through the world today.

In a recent interview for Education Rediscovered, a grassroots student-run campaign mandated to reform global education, Chomsky (2013) spoke about the failure of current education systems to adequately educate the world's young people. Chomsky (2013) is adamant that this is a regressive period in modern, mainstream education where the love of learning is lacking. He believes that there is a growing disengagement with learning which needs to be rectified. The goal of education, he advocates, should be to "develop, not only the capacity but also the desire to gain the information that you need in what you're interested in and what you want to pursue" (2013, 6:35). "Real learning," Chomsky (2013 9:07) advocates, "means gaining the capacity and the interest in discovering." "If you don't have the interest, you aren't going to learn anything," he insists (2013 9:12). Chomsky (2013) and others (Huang, 2014, for example) argue that this desire to learn, or the impetus to discover, is being undermined by goals, which are destructive of what lies at the heart of education.

At the core of any discussion about the foundation and development of any system of education is the question of what is precisely meant by the concept of education and what its purposes should be. U.S. President, Obama, in recent $(2009,2011)$ speeches on the current state and future direction of education in that country, has claimed that education goes hand in hand with the economy and that education should aim to create good and economically useful citizens for a country. As such, Education, from this perspective, is the handmaiden in the service of the economy. To achieve its aims requires reforms to the education system, which has increasingly taken the form of increased teacher and student accountability, increased assessment and the introduction of standardized testing at what, some might argue, is the expense of problem-solving, critical thinking and creativity. Those goals form part of the neoliberal/economic rationalist agenda and are driven by the notion of the maximization of individual or general profit and to maximize individual welfare at the expense of any wider public good. There is a thrust towards the commercialization of education so that individuals are expected to study and to perform in order to increase their human capital and salability in the marketplace (Chomsky, 2013).

To counteract this perception of education, Huang (2014) argues in favor of a broader concept of education which "supports the idea that education should empower people in becoming critical, autonomous but also happy and satisfied rather than passive and economically useful people who blindly believe what authorities tell them" (p. 33). Opponents of the current trajectory of education (e.g., Ackhoff \& Greenberg, 2008) will cite educationalists and social commentators such as Adorno (1998) who advocates for a philosophy of education, the basis of which allows for people to become critical, autonomous and self-reflecting individuals. Dewey (1916) as well, held the 
Smith: Slow down and smell the eucalypts: Blue Gum Community School and the slow education movement

strong belief that students thrive in an environment where they are allowed to experience and interact with the curriculum, and where students should have the opportunity to take part in their own learning. Dewey $(1897,1902)$ advocates for an educational structure which delivers knowledge while also taking into account the interests and experiences of the students. For Dewey, the child and the curriculum are simply two limits which define a single instructional process which incorporates ideas pertaining to learning through active inquiry and experiential learning in authentic situations.

Educationalist, Robinson, speaking at a TED talk in 2010, argues that our current educational paradigm is essentially an industrial or manufacturing model, which he likens to that of fast food production, based on concepts of linearity, conformity, standardization and batching of people (cf. Ritzer's [1993] four primary components of his Mcdonaldization conceptualization: efficiency, calculability, predictability and control). It appears that there is an awareness that current systems are inadequate in delivering the sorts of educated people who are being sought, as Robinson continues by saying that "every education system in the world is being reformed at the moment" (2010, 4:31). He is adamant, however, in his criticism of such reform measures, stating (2010) that any reform measures are simply inadequate because such efforts are "simply improving a broken model" (2010, 4:39). Instead, Robinson advocates for a revolution of the current systems in favor of a model which is based on the principles of what he describes as an agricultural paradigm which acknowledges human flourishing, not as a mechanical process but as an organic process where teachers, educators and institutions create the conditions under which human beings are given the knowledge and skills which will allow them to flourish. The need for fundamental change is not easy, he adds. To challenge the educational systemic status quo and to overturn it, in favor of something more customized for local circumstances, means much more than simple educational reform. According to Robinson (2010), it requires "creating a movement in education in which people develop their own solution but with external support based on a personalized curriculum" (2010, 15:28). Robinson, in summary, urges us to individualize the education system and to encourage engagement, curiosity and creativity, a perspective which runs counter to the current culture of education which is dominated by mechanistic conceptions and controlled by centralized governments and bureaucracies. Robinson insists that, in order for our system of education to satisfy individuals and society at large now and for the future, it needs to substantially devolve responsibility and discretion to the local school level.

\section{Non-Mainstream Education}

For the most part, provision of a common, culturally unifying education and its corollary, schooling, fall under the auspices of local, regional, state or national government ministries or authorities. Opposition to state-run education services has provoked the response of social reformers and individualists, religious believers and romantics (Miller, 2007), educators, parents and students who have declined, for myriad social, cultural, religious or other reasons, to participate in these systems. In response to that opposition, alternative models of schooling and different approaches to teaching and learning have co-existed alongside state-provided mainstream, public education, ever since its inception in the first half of the nineteenth century (Raywid, 1999). Many critics of the public school system often refer to Rousseau's Émile, published in 1762, in which he argued that education should follow the child's innate growth rather than the demands of society, as being the first recorded instance of such oppositional commentary. 
Throughout the nineteenth century, education reformers in several countries accused their state school systems of disciplining young people for the sake of political and social uniformity and the success of an emerging industrial society (Sliwka, 2006). The twentieth century saw the advent of several education movements advocating for non-standard or non-mainstream education which continue to be influential today. The introduction of non-mainstream educational initiatives has a long and strong theoretical and practical tradition developed in the U.K. (Neill, 1960), in Sweden (Key, 1900), Germany (Fröbel, 1826; Lietz, Geheeb, Hahn and the establishment of their reformist rural boarding schools - Landerziehungsheime [State approved school]), Italy ( Montessori, 1912; and her Casa dei Bambini [Children's house]; Malaguzzi and the Reggio Emilia approach), Austria (Steiner), France (Freinet) and the U.S. (Dewey; Parker and the establishment of his school in 1912), for example, some of which today extend their educational philosophies and methodologies globally. It was not until the 1960s and 1970s, however, that alternative education grew into a widespread social movement and it was then that writers such as Illich, Neill and von Hentig (2006) in Europe, Holt, Kozol, Giroux and Kohl in the United States and Freire (2000) in Brazil questioned the values and methods of public schooling.

By the 1990s, the transformation from an industrial to a knowledge economy stimulated a debate about the future of the standard model of schooling (Bereiter, 2002; Bransford, Brown \& Cocking, 2000; Hargreaves, 2003). With the beginning of the $21^{\text {st }}$ century, there has been an increasing groundswell calling for innovative educational projects involving a range of educational approaches that encourage collaborative, participatory and personalized teaching practices and processes developed in non-mainstream school settings. Many teaching practices and initiatives such as student-centered and independent learning, project-based and cooperative learning, as well as authentic assessment are making some headway into mainstream education systems in some jurisdictions.

In an editorial for a recent issue of Other Education: The Journal of Educational Alternatives, Lees (2014) comments that much of the substantial educational research being conducted around the world which qualifies as alternatively-grounded makes use of words such as democratic, autonomous, free, progressive and child-centered in an attempt to indicate an other way (2014, $\mathrm{p}$. 1) when they are not, necessarily, other. Howlett (2013), in his recent book on the history of progressive education in the UK and Europe argues against the use of labels as misleading while Lees (2014) questions the possibility that there is something deeper than words which make the alternatives in education truly other. I argue in this paper that it is neither a name, nor a qualifying adjective, nor any specifically labelled approach to education which is being presented here as "an other way" (Lees, 2014, p. 1). Rather, what follows is a discussion of a burgeoning movement in education, which derives its power as a metaphor from its moral force, which values personal experience, entails making judgments about conduct, virtue, and balance and whose processes and practices are rooted in a belief in the centrality of learning.

\section{Slow Education \& The Slow Education Movement}

Slow Education is a term used to describe an emerging philosophical movement and approach to teaching and learning which allows students to pursue their own interests, become absorbed in their work, care about it and reflect on it - all without the pressure of exams and targets (Barker, 2012). The Slow Education Movement has emerged in England as a reaction to the constraints of the English national curriculum introduced in 1988 and the standards- and outcomes-driven 
programs which have developed as a result (Barker, 2012). It takes its inspiration from the Slow Food Movement which was officially established in Paris when the Slow Food Manifesto was signed in 1989, as a result of a demonstration on the intended site of a McDonald's Restaurant at the Spanish Steps in Rome in 1986 by Petrini and a group of activists (Holt, 2014b). The Slow Food Movement was founded on principles stressing the importance of quality of product, respect for local culture and traditions, cooperation and the use of sustainable methods (Holt, 2014b). Since its inception and with its growth into an international movement, Slow has developed an alternative politico-economic aspect which challenges the notions of globalization and homogeneity in favor of local community initiatives. These tenets have been transferred into many other areas of society-slow travel, slow cities, slow books, slow living, and slow money, amongst others - one of those being into the educational sphere.

It is Holt who is reputed to have coined the term, Slow Education. The analogy came to him, he writes (Holt, 2014b), when he

was thinking about the standards-based school curriculum, with its emphasis on regurgitated gobbets of knowledge, when I recognized the analogy with fast food. What we have created, with our tests and targets, is the fast school, driven by standardized products. So why not devise a Slow School, driven by an emphasis on how ideas are conceptualized, just as Slow Food is driven by how the innate qualities of ingredients can be realized? (para 4)

Gordon (2013), in discussing Honore (2004), suggests that the use of the word slow in the educational context describes a holistic, creative and broad-based transformational approach to teaching and learning which fosters intensity and understanding and equips students to reason for themselves rather than outcomes. Holt (2014a) continues:

An essential aim [of Slow Education] is fostering the ability to understand in depth, and the arts of deliberation are an essential element in this. In slow education, the concept of process is central to the way the curriculum is conceived and experienced. (para 7; emphasis in original)

Slow Education shares something in common with the ancient Greek (Socratic) attitude towards learning: that it is a lifelong process which is intimately bound up with self-development. Proponents of Slow Education (Grenier, 2013a, 2013b; Holt, 2002, 2012, 2014b; Honoré, 2004, for example) argue against the current narrowing of the purpose of education which is dominated by the neoliberal ideology which emphasizes outcomes to deliver knowledge and skills to potential workers in order to satisfy the requirements of the economy. Critics of the traditional schooling system such as Ackhoff and Greenberg (2008) are adamant that the traditional education system is neither realistic nor suited to prepare students to take their place in a modern society. Schools which afford students greater autonomy, responsibility, and a high degree of personal accountability to become self-reflecting, critical and effective individuals, "happy, pleased and eventually ready to take their next steps in life" (Huang, 2014, p. 62) produce what Slow Education proponents would argue are more life-ready and successful (according to their own individual definition of success) individuals. Slow Education, then, is grounded in adaptive, non-standards based approaches to teaching and learning and stands, in part, as a reaction to the overly compacted 
course content requirements, the proliferation of standardized testing which favor quantitative, statistical measures of student and teacher success. According to Grenier (2013b), Eton College House Master and a member of the Slow Education Think-Tank, describes the Slow Education Movement as a return to an education that is flexible, meaningful, long-lasting and above all ethical. Slow Education is avowedly highly academic argues, since learning is valued for its own sake, and where the academic is fundamental in the development and achievement of self-reliant children and adults (Hodgkinson, 2012).

Slow education, Grenier (2013a) stresses, is neither a method nor a system of alternative education. Unlike its Montessori, Sudbury, Steiner, Waldorf and Dalton counterparts, amongst others, the Slow Education Movement does not profess to any particular model of education but, rather, places a heavy emphasis on a certain ethos which drives the teaching and learning environment and which is driven by its unique socio-cultural and socio-economic context. Grenier (2013b) further argues that both the curriculum and physical environment will follow on from this ethos and provide for a rich, active learning experience which is not rushed, where there is sufficient time to engage and learn and where high value is placed upon the quality of the interactions between teacher and learner.

The Slow Education philosophy can thus be an important element in any classroom. Its philosophy and tenets bring to mind an educational environment where students have time to discuss, argue, and reflect upon knowledge and ideas, and so come to understand themselves and the culture they will inherit. Its philosophy has parallels with self-directed learning, project-based learning, challenge-based learning and certain aspects of so-called free and democratic schools, particularly in the provision of ample room for student self-direction and in an environment that esteems the professional judgement of teachers, recognizes the differing interests and talents of its pupils, and works with its community to provide a rich variety of learning experiences.

This paper now turns its attentions to one particular school, Blue Gum Community School (BGCS), situated in the nation's capital, Canberra, Australian Capital Territory (ACT), Australia. This school has gained recent international attention on the Slow Education website (Smith, 2015, p. 4) where it has been flagged as one of the world's educational institutions to have embraced and evolved many of the ethos, tenets and principles ascribed to the Slow Education movement.

\section{Methods}

In an attempt to stimulate and develop increased interest and research in the area of nonmainstream education, research was conducted at BGCS in order to introduce readers and researchers to a uniquely Australian model of education which promotes those very ideals as outlined by Huang (2014) and Robinson (2010). The paper traces the background which led to the establishment of the school, outlines its overarching educational foundations and pedagogical philosophy, and describes how that philosophy is realized in practice through its unique curricula, structure and characteristics.

This paper is at once both deductive and inductive in its approach. Motivation for the investigation of the type of schooling and education offered by BGCS derived from my previous research into the Slow Education Movement and its various theoretical, pedagogical and philosophical underpinnings. The choice in the type of empirical enquiry engaged in and process for data 
Smith: Slow down and smell the eucalypts: Blue Gum Community School and the slow education movement

gathering employed — interviewing staff and directly observing the working environment — was driven by the general theoretical conceptualizations which typify middle-range theory in the sociology of education. In so saying, this paper focuses on empirical research and attempts to understand and explain the workings of a unique educational institution which bucks the mainstream trend and embraces a global educational alternative. Findings ascertained from the interview data and discussions, from the reading of relevant documentation, as well as from the personal observations made, serve to feed back into and build the stock of theory and other findings and interpretations associated with this particular type of non-mainstream education as informed by the principles of the Slow Education Movement.

Preliminary background research was conducted on various websites and school documents and brochures supplied by BGCS or available on its website (Blue Gum Community School, 2013). In response to a request to visit the school, to speak with key executive and teaching personnel, to observe classroom operations in order to gain a deeper understanding of the school and its workings and to gather information and data for this paper, I was invited to the school, where a lengthy, open-ended interview was conducted with three key members of the school-the Executive Director and was introduced to the Education Directors of the Primary School and Middle/High School. Lengthy discussions were held with each of the Directors, during which time I was familiarized with the background, philosophy, structure and curriculum of the school. A tentative, pre-planned schedule of broad-based questions had been prepared but allowed for a very loosely and flexibly directed interview. The style of interview conducted took the form of what has been described by Wengraf (2001, p. 111) as a "lightly-structured depth interview". The format of this type of semi-structured interview affords maximum flexibility and offers respondents the freedom to answer questions in the most relevant and appropriate way.

The interview was conducted informally. The trajectory of the conversation was informed by my objectives to gain a deeper understanding of the history of the school and reasons for its foundation, its philosophical and pedagogical principles, its structure and operation and its perceived successes as a non-mainstream educational institution. The three key members of the school community and various other staff members approached very willingly participated in the interviews, were keen to answer any of my questions and provided me with every assistance. Their responses and comments offered me certain insights into the culture of the school which would allow me to better contextualize my research in the broader context of the Slow Education Movement.

It was not the intention to try and obtain any balance in terms of commentary or responses to questions. Rather, the interviewees formed a purposive sample (Patton, 2002) which reflected generalized opinions of the school, its overarching philosophy, purposes and intentions, its programs, teaching styles and any other commentary about the day-to-day running of the school.

I advised the staff at the commencement of the interview that it was my intention to take notes. I had been somewhat reticent to record this initial interview, as I was unsure as to how any request for recording the session might have been met. Because I saw this meeting as the first in what would develop into an ongoing relationship with the school, its staff and students, I thought it important in the first instance to concentrate on developing a rapport with the Directors and to create a firm basis of trust which might have been compromised had the interviewees felt uncomfortable or constrained if their responses were recorded (de Vito, 2001). 
I was escorted around the school separately by each of the Directors and shown the workings of each of the classrooms for which they had responsibility and observed individual classrooms and students' engagement. I was introduced to classrooms which were configured and furnished in ways completely different to those of mainstream schools, but which created a physical environment and atmosphere conducive to student comfort and learning. I also had the opportunity to experience some working classrooms, where students were engaged in their learning tasks and observed what they were doing and how they were going about their classroom business. I observed students playing outside during the mid-morning break and had explained to me the importance given to play for student learning and socializing - playing with ideas, materials and diverse others. At that time, I was also given a tour of the school grounds, including the specifically-designed play area, chicken coop, vegetable patch, and the arts and crafts and music facilities.

Following the visit to BGCS, my hand-written notes were then typed, and any additional information which I had not noted down included in the transcript, ensuring at the same time that the overall veracity of the content of the interview had not been compromised or inadvertently embellished. To ensure the accuracy of what I had written, a draft of the paper was forwarded to the Executive Director of the school for her and the other Directors' scrutiny of its details and comment regarding its content.

Once the notes were appropriately written up, the data were coded and compared across the number of themes and issues which emerged as a result of the careful analysis of the interview material. It is these themes which have formed the basis of the format for the discussion of BGCS below.

\section{Blue Gum Community School - Background}

Blue Gum Community School (BGCS) began as an extended-hours early learning center for 3and 4-year olds in 1998 and gradually moved into the formal schooling years since 2001. It was established by a group of teachers and parents dissatisfied with what they saw to be an education system failing to keep pace with the rapidly changing world around them. Disappointed with the mass-produced one-size-fits-all approach to education, these teachers and parents banded together to form a not-for-profit community group, Best-Practice Education Group Ltd (BPEGL). After initial difficulties accessing suitable premises, and several relocations, BPEGL has developed BGCS as an independent community-based, secular, non-selective, fee-paying (supplemented by relatively-low levels of government subsidy from the federal and ACT governments) school, which is based upon its own unique, interactive educational model in leased ACT Government premises in the inner northern suburb of Canberra, Hackett. Since 2001, the school has increased its size and now caters for children/students from birth to the end of high school in the ACT (equivalent to Grade 10). Programs include a nature-based Playgroup for under threes and an extended-hours Pre-School for children aged three to five years of age. The school population recorded in the 2013 government census consists of 76 students ( 38 females; 38 males) enrolled in the Pre-School, and 90 students (49 females; 41 males) in the Primary/Middle/High Schools, the latter with a staff of six full-time and five part-time female teachers (Blue Gum Community School, 2013). As is a requirement for all teaching staff within the ACT jurisdiction, classroom teachers at BGCS possess a four-year teaching qualification from a recognized institution, are registered with, and satisfy the requirements of the ACT Teacher Quality Institute (Blue Gum Community School, 2013). 
The school was founded along educationally progressive lines and embraces a philosophy of viewing each and every child/student as highly competent, capable, creative, responsible, resourceful and resilient, who therefore learns best through deep extended learning experiences where students actively engage in the exploration of individual and community interests/questions/theories for knowledge-gaining and meaning-making. Hartung, Executive Director and a founding principal of Blue Gum Community School (BGCS), rejects attempts to describe the education and schooling offered at BGCS as alternative (personal communication, July 24, 2014). In non-educational circles, the notion of alternative education is often associated with the ideas of deficiency and opportunity: a deficiency in the provisions of mainstream education and the opportunity of providing a system of education or style of schooling which cultivates students' learning through an approach which stands outside conventional teaching and learning approaches.

Whilst the founders of the school were impressed with non-mainstream educational research emanating from Scandinavian countries, Italy and the United States, it was always their intention to develop a learning environment that reflects experiences elsewhere, but is uniquely positioned within the Australian context, rather than simply importing models from other countries or previous eras (Hartung, personal communication, July 24, 2014). Reference points that have offered valuable sources of reflection include the Reggio Emilia experience, Big Picture Education, Nature Education, Place-based Education, Project-based Learning, Positive Psychology, and the writings of Holt and his principles of Slow Education (Holt, 2002, 2012). By slowing down the learning process, and giving students time to engage deeply for extended periods, the curriculum and the way in which it is formulated invites students to be active players in knowledge acquisition, resulting in their greater engagement with, commitment to and ownership over their learning.

While the school does not subscribe to any single or specific philosophy or approach, it has adopted a perspective which is ever-evolving and which resonates with the historical, social, cultural, political and economic milieu within which it has been created and continues to develop. Hartung (personal communication, July 24, 2014) has stressed that while the guiding philosophy, principles and practices associated with BGCS may be perceived as non-mainstream, the teaching and learning philosophies do not stand in opposition to mainstream modes of education and schooling. Instead, because the school views itself as a research center rather than an information transfer center, the slower-paced style of education places high academic expectations on students and emphasizes quality learning opportunities which extend beyond replicating information to theorizing, reflecting, discussing, testing and reframing ways of meaning-making. In part, this approach is also "interest-driven, child-led, organic or eclectic learning" (English, 2013, para 4).

\section{Teaching and Learning at BGCS}

BGCS adopts a very strong learner-responsible, as opposed to a more traditional teacherresponsible, model (Armstrong, 2012). Such a model rests on the premise that an approach which values the interests and learning styles and capacities of an individual is more effective than one directed by others. Armstrong (2012) writes:

If learners are the producers of learning, the teacher-responsibility inhibits learning. Efforts to improve the teacher-centered approach reduce learner responsibility. The 
solution is straightforward: Allow people to take responsibility for their learning. (p. 5)

The role of the teacher at BGCS parallels Dewey's (1897) re-imagination of the way in which the learning process should take place, and the role which the teacher should play within that process. According to Dewey (1897), the teacher should not be one to stand at the front of the room disseminating information to be absorbed by passive students. Instead, the teacher's role should be that of facilitator and guide. As Dewey (1897) explains it:

The teacher is not in the school to impose certain ideas or to form certain habits in the child, but is there as a member of the community to select the influences which shall affect the child and to assist him in properly responding to these. Thus, the teacher becomes a partner in the learning process, guiding students to independently discover meaning within the subject area. (Article 2, para 14)

Teachers at BGCS, therefore, articulate their classroom contexts "in ways that are pluralistic and facilitative - giving space for students to find their voices and speak out in a setting that contains divergence" (Akomolafe \& Dike, 2011, p. 15). Students, however, are not given the flexibility and freedom to totally design their learning path to adulthood, as is the case in less structured schooling systems such as the so-called democratic schools (Galley, 2004) and Sudbury schools. Instead, they are afforded opportunities to negotiate and direct their own learning. The curriculum implementation is strongly influenced by students' responses to initial learning provocations, designed by teachers balancing personal engagement and community expectations.

Skills and outcomes targeted include the ability of students to risk-take and persevere through new challenges; learning how to make effective judgments and to constructively critique their own work and that of others; the capability to pursue their passions, interests and questions to a deep level of understanding; the capacity to adapt to change; and openness to innovation and creativity in solving problems. There is a strong belief that this way of working with students requires them to be trustworthy and responsible community members, who can manage their own learning, stand accountable for their actions, set priorities, deal with and explore complex issues, and work cooperatively with others. Students learn to balance individual freedom, wants and needs with broader community responsibilities, expectations and constraints.

\section{Structure and Curriculum}

BGCS teaching staff liken their educational project to an organic structure-something which is constantly in development and which has few intellectual boundaries. To describe their curriculum as amorphous would be to suggest that the processes behind and which inform the teaching and learning have, at best, vague goals or trajectories. Nothing could be further from the truth. There are clear teaching and learning objectives which are continually being assessed and re-assessed by teachers and students alike. Teachers' assessment of student learning is not limited to measuring prescribed curriculum outcomes, but encompasses actual achievements to be celebrated alongside areas identified for further work. In line with mandated government policy, students' learning is then linked to and matched against the Australian Curriculum and ACT curriculum framework requirements. 
Smith: Slow down and smell the eucalypts: Blue Gum Community School and the slow education movement

Knowledge is viewed as a co-construction of meaning rather than an imposition of facts, with the consequence that such a transgressive approach to education brings teachers much closer to the developmental and intellectual needs and preferences of their students in a manner which is neither inhibitory nor limiting. Students engage in active and useful learning tasks for which they set a number of achievable objectives each day and which are assessed by themselves and by their peers. Having clear, well-stated and realistically achievable objectives promotes learning success (Locke \& Latham, 2002).

\section{The Learning Environment at BGCS}

Timetabling at BGCS is quite flexible and open to negotiation. There are none of the traditional bells to indicate class or break times, so as to minimize disruption to learning, exploration, research, discussion or debate in which students may be involved. Classrooms open at 8:30am, with compulsory core hours being from 9am to $3 \mathrm{pm}$. The school day is divided into three broad exploration and learning sessions: a morning tea break is taken mid-morning for an hour, with a lunch break in the middle of the day for half an hour. Time outdoors, investigating the natural world or engaged in student-directed activities, is valued as an important part of an Australian inheritance, as well as a resource-rich opportunity for learning. Recreation is seen as a vitally important time for students to develop outdoor interests and to learn how to relate socially and interact with others through play and informal activities. The school's playgrounds, reinvented and re-designed in collaboration with a landscape architect, minimize fixed equipment (climbing frame, treehouse, basketball court, beach volleyball court, kitchen gardens) and maximize openended wild spaces that elicit imaginative and exploratory play and investigation. Students may borrow more traditional equipment for games/sports (e.g., balls, bats, racquets, skipping ropes, gardening tools), or use loose parts (e.g., tires, hay bales, sticks, wood, ropes, fabric) for construction or to create small worlds up or in among the climbing trees, boulders and bush.

The Hackett Campus of the school houses the primary, middle and high schools and playgroups, while the pre-school is located in the neighboring suburb of Dickson. A team of Education Directors - Hillam, Williams and Grimm - complement their everyday practice as classroom educators with weekly release days for their role working pedagogically with other teachers. There are four multi-age primary school classes covering the traditional Kindergarten to Grade 6, and two secondary school classes that overlap Grade 6 through to Grade 10. Each class has its own Class Director, who manages the learning program for that class; each Class Director is allocated a weekly release day to undertake their professional planning/programming/documentation/ research. Younger classes include a second full-time educator to cater for 25 students; senior classes have 14-16 students. Specialists teach Visual Arts, Music/Drama, Outdoor Education, Sport (the focus changing each term), Italian, and the Stephanie Alexander Kitchen Garden program. Senior students also undertake community-based learning opportunities off-campus.

Primary school classes are identified by names, rather than represented by any numerical indication of year level. The names were chosen by student ballot after they researched options: Scribbly Bark, Ironbark, Flame Tree and Coolabah derive from names of iconic Australian tree species and, emblematic of the Australian natural environment, also complement the name chosen for the school (Blue Gum - a robust Australian native eucalypt tree). Structurally, the senior classes are a variation of the primary school format, but currently the students have chosen to identify themselves simply as Middle School and High School. 
Classrooms at BGCS reflect the holistic approach to education which permeates the whole school environment. The traditional set-up of classrooms has been "deliberately discontinued" (Sliwka, 2006, p. 6). The rooms are spacious and divided into various learning spaces - writing, reading, tinkering/construction, science, art, and mathematics - which bear little resemblance to the more formal structure of traditional classrooms with desks arranged in rows, an exposed teacher's desk and a board in the front of the room. The learning environments are flexible and organic, organized so as "to put the learner center stage, to provide a wide array of learning resources and to facilitate individual as well as collaborative learning" (Sliwka, 2006, p. 6). Couches, rugs, bookcases, repurposed wooden dining tables, curiosity items, jigsaw puzzles and board games, light tables, displays of enticing resource materials, lounge chairs and cushions signifying quiet reading spaces, an eclectic mix of recycled household furniture, indoor plants, indoor aquaria, all go towards creating a variety of welcoming, focused and productive working spaces within a richly provocative environment. Each classroom offers a unique, constantly-changing educational setting, carefully prepared with learning intent by the Class Director. Students, I was told, "are here because they want to be here-even returning unprompted to visit classes after they graduate" (Hartung, personal communication, July 24, 2014). Students in each class are conscious of being members of a classroom community' and, as such, have a responsibility towards the other members of their class. Students are expected to help maintain the classroom aesthetic and be cognizant of the need to balance hands-on exploration with consideration for subsequent explorers. Because different students make use of different areas and facilities at different times, the onus is on the students to maintain an inviting environment, conducive to maximizing the learning of each of its users.

\section{The Role of Teachers}

Teachers are never seen as mere agents of curriculum delivery. With varying degrees of intervention, the teacher role ranges from being a coach on the side that students can draw on (but do not have to) to a provider, organizer and manager of customized learning in experiential learning environments (Sliwka, 2006). Teaching, learning and knowledge creation occur through negotiated learning choices, exploration, investigation and research, discovery, discussion, debate, analysis, theorization and activity, with an emphasis on collaborative learning.

The research focus in each classroom starts with teacher-created invitations for learning that emerge from myriad sources-contemporary events; knowledge of the students' interests; and curriculum learning areas. Class Directors plan for possible directions for the research, but are ultimately guided by the way students respond to these triggers for learning. By closely observing and listening to the way students engage with a learning provocation, teachers distil their emerging research questions, which students are highly motivated to investigate further. While specific subjects or outcomes are not often pre-determined, there are expectations of certain levels of attainment of particular skills at the various levels. Through targeted workshops, there is explicit teaching of core fundamentals, such as reading, writing, and mathematical concepts and processes. However, the most powerful learning emerges from the dynamic and interactive process at BGCS. Students are not only restricted to individual learning but are encouraged to work in small groups, which helps to develop their social and interpersonal skills and offer intellectual benefits, as well as challenging and extending their thinking. There is a strong belief that every student possesses a unique set of strengths which can contribute to others' understanding and learning, as well as possessing areas requiring development or extension which can be supported by others in the class. 
Smith: Slow down and smell the eucalypts: Blue Gum Community School and the slow education movement

Those students possessing particular knowledge or skill sets are often drawn upon to provide their expertise in particular fields or endeavors.

Teachers at BGCS are at once intuitive and responsive to what is happening in the classroom. They listen carefully to students and plan teaching and learning strategically in response to students' questions and needs. In each classroom, teachers set up a variety of Explorations for students. Explorations are open-ended weekly tasks/research options, prepared by each Class Director as a starting point for student investigation. They are designed to suit the ages and extend the ability levels of the students in the class. These tasks generally fall within/across Blue Gum's STEAM $\mathrm{H}$ categories (Science, Technology, English, Arts, Mathematics, and History, including a tangible piece that gradually builds the research project under investigation). Students are given considerable latitude as to the process and sequence they adopt for tackling these endeavors, which respects students' different learning styles. However, high expectations as to the quality of the work are embedded in a process of multiple drafts, whereby work is revisited several times and refined, following self-reflection as well as critiquing by peers and teachers. Slowing down the process and inviting scrutiny by others are essential elements in the learning process. In the early years of schooling, or for students new to this style of education, more intensive teacher support is initially required to ensure student success in managing the workload. Over time, this level of support reduces as students map out and practice the approach to learning that best works for them. However, the goal of lifelong, self-directed learning remains the same, irrespective of grade level.

Because the classroom focus is predominantly on students engaging with learning Explorations or research rather than teacher instruction, teachers closely observe and get to know their students very well and learn how each one interacts, responds, and learns best. Teachers offer a range of learning Explorations or research options which can be pursued and achieved by students in their own ways. Teachers plan for possibilities and contingencies, rather than pre-determining an outcome. The direction learning takes is thus very much a process of evolution. However, Hartung explained "it is definitely not a program of indulgence that simply follows students' whims" but instead it "looks for legitimate research opportunities that arise in the process of learning" (personal communication, July 24, 2014).

Teachers do not prescribe a term's (approximately 10 weeks in the Australian context) curriculum in advance with pre-determined student outcomes to be achieved. Rather, possible lines of enquiry are planned for, and actual learning outcomes documented retrospectively. Teachers plan intensively for the week ahead, but even that plan may vary depending on the trajectory of students' learning during that week, or unexpected circumstances which might arise. This process and structure stands in direct contrast to a traditional approach to curriculum development adopted by most Australian schools. This is not to suggest that curriculum developed at BGCS may be described as laissez-faire. On the contrary, BGCS's emergent negotiated curriculum has been developed in accordance with the guidelines for school registration purposes, required by the government agency, the Education and Training Directorate of the ACT. Policy mandates that planning and documentation for all ACT schools are required to reflect the outcomes and pedagogical responsibilities of the teaching fraternity of the ACT as detailed in the ACT curriculum framework document, Every Chance to Learn and the Australian curriculum which is currently being gradually implemented across the country (ACT Department of Education, 2007). 


\section{Community, Accountability and Responsibility at BGCS}

The notion of community is integral to an understanding of the philosophy of BGCS. At all levels of the education process, students are members of the community of learners in their classroom, develop "a sense of community where all members have a sense of belonging", establish "an extended community through a mentoring relationship with younger classes", explore "intergenerational opportunities with senior members of the local community", and carry out "action research projects within the broader Canberra community" (Blue Gum Community School, n.d.b, p. 2). Influenced by Big Picture Education's 3R's of Relevance, Rigor and Relationships in real-world contexts, BGCS expects that all high school students "undertake intensive and personally-demanding Community Research Internships, where they negotiate with a mentorexpert/business/community group - to undertake a mutually-beneficial authentic research project off-campus for an extended period" (Blue Gum Community School, 2013, p. 1). As part of the usual lead-up, students create a Curriculum Vitae, and write a letter of introduction outlining their interests, what they wish to accomplish during and as a result of their internships, and how their project will be of benefit to the individual or organization. Students attend interviews and often shadow potential mentors in order to ensure that it is what they and the individual or organization are looking for. Students then spend one day each week undertaking their research project in the real world; projects may last anywhere from one term to two years and form a vitally important part of the high school curriculum. Because of their protracted nature and research focus, these extended internships differ from the more traditional work experience provisions made in other Australian schools. These Community Research Internships afford students an authentic engagement with the world beyond the school walls and an opportunity to apply their research skills in ways that students find highly motivating and personally rewarding.

BGCS views the educational process as a learning continuum. Students' development is viewed and supported along a 5-point learning continuum-novice, apprentice, practitioner, expert, mentor. Knowledge is not simply owned as a personal achievement, but is valued as a community resource or asset which is fully realized in the mentoring role. Over time, students come to appreciate the lifelong nature of learning and to value opportunities to spend time working alongside experts: scientists, artists, writers, poets, coaches, photographers, musicians, for example. These community members are passionate and knowledgeable, and are usually generous in sharing their expertise with enthusiastic learners. The traditional image of the classroom teacher as the infallible expert is dethroned, as they become a co-learner alongside the students, and a genuine community of learners takes over. Given that today's workplace places greater emphasis on an employee's abilities not just to function independently but, increasingly, to be critical, constructive and collaborative workers, these opportunities and exposure to the broader community are beneficial to the development of students' overall life skills and their ability to handle work-life expectations.

BGCS teaching staff are very conscious of, and committed to, this broader sense of community, and the need to recognize students as citizens with rights from birth. These include the right to have a visible presence and to be listened to as a valuable community contributor, not merely prepared by schooling for citizenship as a future adult role. An image of the student as competent, capable, creative, responsible, resourceful and resilient informs all aspects of the learning process, and is a pre-requisite for the best educational grounding students can receive to ensure that they are well-equipped with the necessary competencies and strategies to confront life's challenges. 
Smith: Slow down and smell the eucalypts: Blue Gum Community School and the slow education movement

Coupled with the notion of community is that of accountability. Students are accountable for their actions and responsible, not only to themselves, but to their peers, teachers, parents, carers and the broader community. (A parallel expectation applies to the professional teaching staff.) The social and emotional well-being and a real sense of belonging are integral to the welfare of each student at BGCS. Because students are active participants and negotiators of their learning and research endeavors, they assume greater ownership over, commitment to and responsibility for their own learning. The degree of success or learning achievement is made more tangible through a process of peer accountability. For instance, high school students meet in pairs before learning sessions to discuss their goals for that session. At the end of the session, the pairs meet again to discuss what each has actually achieved, their challenges/impediments and strategic responses. At the end of the day, pairs may have a further meeting to reflect on the day's work and any follow up needed, such as taking incomplete work home to ensure deadlines are met.

Because BGCS adopts a strengths-based focus (rather than the traditional deficit model), standardized tests/grades using a bell-shaped curve are unhelpful in informing the learning process, as different students are usually pursuing different research endeavors. However, diagnostic testing is carried out by teachers to assess students' core skills and their need for, and inclusion in, regular targeted workshops. An important and essential part of the BGCS learning process (which parallels workplace performance reviews) involves ongoing constructive critical comment and feedback from teachers and peers to pinpoint targets and strategies for individual learners' selfimprovement. This co-opt rather than coerce approach is mirrored in the school approach to discipline. By contrast with the traditional reward/punishment system where attributing blame promotes denial of responsibility or exclusion, BGCS endorses a problem-solving focus which fosters acceptance of responsibility and inclusion-reinforced in the classroom through the teaching of "effective relationship and communication skills - a repertoire of negotiation and problem-solving skills" (Blue Gum Community School, n.d.a, p. 1).

\section{Conclusion}

The idea that the global state of education is in crisis is not new. Arendt's The Crisis of Education, published in 1954, for example, encouraged engaged thinking and public discussion and debate around the need for educational restructuring and reform and continues to be massively relevant to the ongoing conversation about the state of education today. A similar theme is promoted by Coombs in his 1968 landmark book, The World Educational Crisis, updated in 1985 as The World Crisis in Education: The View from the Eighties which argues that the world of education has been enveloped in a range of profound critical problems, the underlying causes of which need to be overcome in order to rectify global educational disparities. In fact, education journals, reports, and dialogues among educators are filled with references to the need for and methods of restructuring education. Educational restructuring and reform are being implemented in state policies and local schools around the world. Such restructuring is fragmented and unclear in its purpose and direction and takes many different approaches. Any such restructuring must be grounded in a broad understanding of the basic contract between education and society and the ways in which that contract and set of relationships must be changed to meet individual, community, and national needs (McCune, 2002).

Increased accountability of schools, teachers, students and administrators, pressures on schools to improve their performance levels, the publication of school results and league tables "for arranging 
schools in rank order" (Holt, 2012, para 9), the promotion of competition as a positive force for good education and educational success are all features of today's education systems. The provision of standards-and outcomes-driven educational services and opportunities are governed by a belief that a major purpose of education is to provide work-ready individuals who are to play a role in sustaining economic and human resource needs. In a move to counterbalance the current neoliberal/economic rationalist agendas which dominate contemporary education programs and systems of schooling, there is a growing interest in educational philosophies which place learning, rather than test-based knowledge (Holt, 2012), as their core focus.

The criticism of the standard model of education has gained support. There is a certain growing disquiet with the traditional transmission and acquisition model of schooling which fails to focus the instructional methodology on learner experience and reflection, for example. Those who challenge the traditional form of education also advocate for integrated curricula and a focus on independent and customized learning combined with formative assessment, fostering competencies rather than conveying knowledge. There is evidence that the knowledge society's need for more integrated and usable knowledge is best met by more integrated and deep (rather than broad) curricula (Sliwka, 2006). Sawyer (2006) suggests that traditional structures of schooling "make it very hard to create learning environments that result in deeper understanding" (p. 3). These findings provide backing for the experiential, project- and problem-based and collaborative learning that schools such as BGCS have been focusing on and within whose constructivist learning environments, students gain expertise from a variety of sources beyond the teacher (Greeno, 2006).

It has been demonstrated that, whereas traditional schools generally practice a one size fits all model, according to which every student of a certain age is supposed to learn the same thing at the same time, BGCS provides its students with a customized learning experience, where the potential effectiveness of individualized forms of learning is enhanced by a learning setting which is sensitive to the learners' pre-existing cognitive structures. The practice of more independent, negotiated forms of learning also seems to prepare for the knowledge society's requirement of intrinsically-motivated individuals who are able to take responsibility for their own continuing, lifelong learning.

The pedagogical foundations and teaching and learning strategies in place at BGCS have been influenced by several different yet remarkably compatible approaches that have emerged in different parts of the world, such as Slow Education, the Reggio Emilia experience, Big Picture Education, Place-Based Education, Project-Based Learning and Positive Psychology. They follow in a long tradition which rests upon a belief espoused by Aristotle, who argued that "every human being is curious" (Huang, 2014, p. 35). Observation with open-ended research and expert interviews (Flick, 2006) has provided the opportunity to see an example of the principles and ethos of a slow school in practice, and to see first-hand, students enthusiastically engaged in pursuing knowledge, skills and understanding through enquiry-based, deep learning.

A strong belief of the Slow Education Movement is that there is no single way to approach education but that the methods and strategies employed in each iteration of a slow school should reflect the school's mission, vision, how it defines itself within the concept, and its social, cultural, historical and local community context. Whilst BGCS has been established along identifiable 
Smith: Slow down and smell the eucalypts: Blue Gum Community School and the slow education movement

ideological lines, staff embrace education as an evolutionary and responsive process so that their teaching and learning environment remains flexible and open to change, in tune with pedagogical development and community views and perspectives, and ultimately focused on the twin elements of researching and learning, with students and teachers working as partners and active players in this process.

\section{References}

Ackhoff, R., \& Greenberg, D. (2008). Turning learning right side up: Putting education back on track. Retrieved from https://www.nigerianseminarsandtrainings.com/articles-pdf/47.02.TurningLearning.pdf

Adorno, T. (1998). Education after Auschwitz. In T. Adorno, Critical Models: Interventions and Catchwords, pp. 191-204. New York: Columbia University Press. Available at http://www.deschoolingclassroom.tkhgenerator.net/wp-content/uploads/2009/12/adorno-education_after_auschwitz.pdf, originally published in German as 'Erziehung nach Auschwitz'. In, T. Adorno, Erziehung zur Mundigkeit. Frankfurt am Main, Germany: Suhrkamp Verlag.

Akomolafe, A. C., \& Dike, I. P. (2011). Decolonizing education: Enunciating the emancipatory promise of nonWestern alternatives to higher education. Paper presented at the XII International Seminar on Globalization of Higher Education: Challenges \& Opportunities. New Delhi, India, January 4-5.

Arendt, H. (1954). The crisis in education. Retrieved from http://scholar.google.com.au/scholar url?url=https://www.thecriticalreader.com/wpcontent/uploads/2016/07/ArendtCrisisInEdTable.pdf\&hl=en\&sa=X\&scisig=AAGBfm140zXbQM_BcLR761GKbimOKVLfg\&nossl=1\&oi=scholarr\&ved=0ahUKEwjn3eW00NPWAhXCErwKH SaVBmUQgAMIJSgAMAA

Armstrong, J. (2012). Natural learning in higher education. Encyclopedia of the Sciences of Learning, 1, $2426-2433$.

Australian Capital Territory, Department of Education and Training. (2007). Every chance to learn: A curriculum framework for ACT schools-Preschool to year 10. Retrieved from http://activated.act.edu.au/ectl/framework.htm

Barker, I. (2012, November 2). Find the time for slow education. Times Education Supplement Scotland. Retrieved from http://www.tes.co.uk/article.aspx?storycode $=6298869$

Bereiter, C. (2002). Education and mind in the knowledge age. Mahwah, NJ: Erlbaum.

Blue Gum Community School. (2013). Annual report 2013. Retrieved from http:/www.bluegum.act.edu.au

Blue Gum Community School. (n.d.a). Blue Gum Community School prospectus. Canberra, Australia: Blue Gum Community School.

Blue Gum Community School (n.d.b). Middle school considerations. Canberra, Australia: Blue Gum Community School.

Bransford, J., Brown, A., \& Cocking, R. (Eds.). (2000). How people learn: Brain, mind, experience, and school. Washington, DC: National Academy Press.

Chomsky, N. (2013). Noam Chomsky: Education rediscovered [Interview transcript]. Retrieved from Education Rediscovered YouTube Web site: http://www.youtube.com/watch?v=Ls6D055tjwo.

Coombs, P. (1968). The world educational crisis: A system's analysis. New York, NY: Oxford.

Coombs, P. (1985). The world crisis in education: The view from the eighties. New York, NY: John Wiley.

De Vito, J. (2001). The interpersonal communication book. ( $9^{\text {th }}$ ed.) New York, NY: Longman.

Dewey, J. (1897). My pedagogic creed. School Journal, 54, 77-80. Retrieved from http://dewey.pragmatism.org/creed.htm

Dewey, J. (1902). The child and the curriculum. Chicago, IL: University of Chicago Press.

Dewey, J. (1916). Democracy and education: An introduction to the philosophy of education. New York, NY: Macmillan.

English, R. (2013). 'Unschooling'_Education fad or real alternative? The Conversation. Retrieved from http://theconversation.com/unschooling-education-fad-or-real-alternative-12548.

Flick, U. (2006). An introduction to qualitative research. Thousand Oaks, CA: Sage.

Freinet, C. (1994). Euvres pédagogiques. Paris, France: Seuil.

Freire, P. (2000). Pedagogy of the oppressed. London, England: Continuum.

Fröbel, F. (1826). Die Menschenerziehung, die Erziehungs-, Unterrichts- und Lehrkunst, angestrebt in der allgemeinen deutschen Erziehungsanstalt zu Keilhau. [Human education, the art of education, teaching and 
learning, sought after in the general German educational institution at Keilhau]. Leipzig, Germany: Keilhau.

Galley, M. (2004). Free rein. Education Week, 23(36), 27-31.

Giroux, H. (1978). Developing educational programs and overcoming the hidden curriculum. Clearing House, $52(4), 148-151$.

Gordon, A. (2013, February 3). Slow movement author Carl Honoré takes aim at the quick fix. The Toronto Star. Retrieved from http://www.thestar.com/news/insight/2013/02/03/slow_movement_author_carl_honor_takes_aim_at_the_q uick_fix.html

Greeno, J. G. (2006). Learning in activity. In R. Sawyer (Ed.), Cambridge Handbook of the Learning Sciences (pp. 79-96). New York, NY: Cambridge.

Grenier, M. (2013a). Slow education: Facts and knowledge vs deeper learning. Retrieved from http://sloweducation.co.uk/2013/06/10/slow-education-facts-and-knowledge-vs-deeper-learning-by-mikegrenier-2/

Grenier, M. (2013b). Some thoughts a year on. Retrieved from http://sloweducation.co.uk/2013/10/01/somethoughts-a-year-on-by-mike-grenier/

Hargreaves, A. (2003). Teaching in the knowledge society: Education in the age of insecurity. New York, NY: Teacher's College Press.

Hodgkinson, T. (2012, December 12). We need to take education slowly. The Independent. Retrieved from http://www.independent.co.uk/voices/commentators/tom-hodgkinson-we-need-to-take-education-slowly8412116.html

Holt, J. (1995). How children fail. New York, NY: Perseus.

Holt, M. (2002). It's time to start the slow school movement. Phi Delta Kappan, 84(4), 264-271.

Holt, M. (2012). Slow schools mean deep learning. Retrieved from http://sloweducation.co.uk/2012/06/22/the-casefor-slow-education-by-professor-maurice-holt/

Holt, M. (2014a). Slow education: Possibilities for research and development. Retrieved from http://www.localschoolsnetwork.org.uk/2014/04/slow-education-possibilities-for-research-anddevelopment/

Holt, M. (2014b). The nature and purpose of education. Retrieved from http://www.ecoliteracy.org/essays/natureand-purpose-education

Honoré, C. (2004). In praise of slow: How a worldwide movement is challenging the cult of speed. London, England: Orion.

Howlett, J. (2013). Progressive education: A critical introduction. London, England: Bloomsbury.

Huang, V. (2014). Laying the foundations for democratic behavior-A comparison of two different approaches to democratic education. Journal of Unschooling and Alternative Learning, 8(15), 30-68.

Illich, I. (1996). Deschooling society. London, England: Marion Boyers.

Key, E. (1900). The century of the child. (translated by Marie Franzos). New York, NY: G. P. Putnam.

Kohl, H. (1998). The discipline of hope. New York, NY: Simon and Schuster.

Kozol, J. (1972). Free schools. Boston, MA: Houghton Mifflin.

Lees, H. (2014). Editorial: A certain sensibility for alternatives? Other Education: The Journal of Education Alternatives, 3(2), 1-2.

Locke, E. \& Latham, G. (2002). Building a practically useful theory of goal setting and task motivation: A 35-year odyssey. American Psychologist, 57, 705-717.

McCune, S. (2002). Restructuring education. In D. Dickinson, (Ed.) Creating the future: Perspectives on educational change (pp. 162-182). Aston Clinton, Bucks, UK: Accelerated Learning Systems Limited.

McLean, M. (1986). A world educational crisis? Compare. A Journal of Comparative and International Education, 16(2), 199-211.

Miller, R. (2007). A brief history of alternative education. Retrieved from http://www.educationrevolution.org/history

Montessori, M. (1912). The Montessori method: scientific pedagogy as applied to child education in the children's houses. New York, NY: Frederick A. Stokes.

Neill, A. (1960). Summerhill School: A radical approach to child-rearing. New York, NY: Hart.

Obama, B. (2009, September 9). My education, my future: Obama addresses school kids [Transcript]. Retrieved from $\mathrm{http}: / / \mathrm{www}$.youtube.com/watch? $=47 \mathrm{c} 6 \mathrm{z} 2 \mathrm{mrTEM}$ 
Obama, B. (2011, March 14). Remarks by the President on Education in Arlington,VA. Kenmore Middle School, Arlington, VA. [Transcript]. Retrieved from http://www.whitehouse.gov/the-pressoffice/2011/03/14/remarks-president-education-arlington-virginia

Patton, M. (2002). Qualitative research and evaluation methods. Thousand Oaks, CA: Sage.

Raywid, M. (1999). History and issues of alternative schools. The Education Digest, 64(9), 47-51.

Ritzer, G. (1993). The McDonaldization of society. Thousand Oaks, CA: Pine Forge Press.

Robinson, K. (2010, February). Bring on the learning revolution [Video file]. TED 2010 Long Beach, CA. Retrieved from http://www.ted.com/talks/sir_ken_robinson_bring_on_the_revolution\#t-3099

Rousseau, J.-J. (1762). Emile, or on education. Trans. by A. Bloom. New York, NY: Basic Books.

Sawyer, R. K. (Ed.) (2006). Optimising learning: Implications of learning sciences research. Paris, France: OECD, Centre for Educational Research \& Innovation.

Sliwka, A. (2006). The contribution of alternative education. Retrieved from http://www.oecd.org/edu/ceri/40805108.pdf

Smith, S. J. (2015). Slow education down under: The slow education movement at Blue Gum Community School. Slow Education. Retrieved from http://www.sloweducation.co.uk

Steiner, R. (1965). Education of the child in the light of anthroposophy. Forest Row, England: Rudolf Steiner Press. van Oostrum, L. (2014). South Africa's Outlaw Educators. Other Education: The Journal of Education Alternatives, $3(2), 74-81$.

von Hentig, H. (2006). Die schule: Neue denken. [School: New Thoughts]. Weinheim, Germany: Beltz.

Wengraf, T. (2001). Qualitative research interviewing: Biographic narratives and semi-structured methods. Thousand Oaks, CA: Sage. 